\title{
Development of private subsidiary farming among the population of the Republic of Kalmykia (based on the results of the field research in 2017)
}

\author{
Lyudmila Namrueva \\ Kalmyk Scientific Centre of the RAS \\ the Department of integrated monitoring and \\ information technologies \\ Elista, Russia \\ lnamrueva@yandex.ru
}

\begin{abstract}
The Republic of Kalmykia is a large agrarian region, specializing in meat cattle breeding. The region actively participates in the implementation of the country's food security programs. The population in personal parttime farms, peasant (farmer) farms increases the livestock population, thereby solving the problems of the material well-being of the family and developing the agrarian economy of the republic. The article uses the results of an author's study conducted in rural areas. The questionnaire survey of 385 people allowed to examine the degree of marketability of individual farms, the motivation of economic behavior of rural residents.

Keywords: rural population, personal subsidiary farming, agrarian reforms, livestock
\end{abstract}

\section{INTRODUCTION}

The beginning of the agrarian reforms in the 1990s was correlated with a sharp fall in the level of social welfare of the rural population, the lack of social stability and guarantees. During this period people in the village community began to take up the subsidiary production as a means of survival in terms of hard social and economic conditions. Private subsidiary farming having become the main producers of agricultural products dominates at the consumer market of livestock products. Since the beginning of the agrarian reforms, keeping and growing livestock in personal farmsteads has been the basis of survival for the majority of the rural residents. Families due to the regular sale of meat, which was their main source of income, solved many life problems (entering a university, weddings arrangements, house-buying etc.) [1].

\section{MATERIALS AND METHODS (MODEL)}

We believe that it is necessary to investigate the potential of private subsidiary farming, the ability of the village community to run private farmsteads and to participate in the transformation of the rural life. It is precisely the investigation of these problems that is the aim of our article, in which it is planned to consider the results of a mass questionnaire survey conducted by the author in the rural areas of the Republic of Kalmykia in the summer of $2017(\mathrm{~N}=385)$. The residents of the rural municipalities (54.6\% of the sample) and the regional centre $(45.4 \%)$ were involved in the survey. The distribution according to the gender and the ethnic identity is represented in the following way: men make up $51.6 \%$, women - $48.4 \%$; the Kalmyks represent the majority of the sampling frame - 77.2\%, the Russians $15 \%$, the representatives of other ethnic groups make up $7.8 \%$. The opinions of the representatives of the two main ethnic groups in the republic - the Kalmyks and the Russians - are analyzed in our survey. The experience of T.G. Nefedova from the Institute of Geography, Russian Academy of Sciences is used in the methodological tools.

\section{RESULTS AND DISCUSSION}

The marketability is considered to be one of the indicators of private subsidiary farming. T. Nefedova defines marketability in the following way: "If the private subsidiary farming sold more than half of what it produced, it was classified as commodity-based farming, if less than half - as a low-commodity farm. If everything was consumed in the family, and sales were occasional, then such kind of subsidiary farming was regarded as self-sufficient one"[2].

The data received on the closed question "Could you describe, please, your commodity productivity?" with four variants of answers make it possible to differentiate the private subsidiary farming of the population on a material basis. Thus, $17.3 \%$ of the respondents living in 
villages sell more than half of what they produce, therefore, the subsidiary farms of these respondents will be classified as commodity-based, materially prosperous. The marketability of farms in the villages $(17.3 \%)$ is much higher than in the regional centers (7.0\%). According to the national identity of the respondents, the following peculiarities are observed: private subsidiary farming of the Kalmyk people $(16.4 \%)$ has a more market orientation in comparison with the Russian one (6.1\%). In the gender perspective, there is also a significant difference: $23 \%$ of men and $7 \%$ of women have the opportunity to sell more than half of what they produce in their farmstead. In general, about $12-15 \%$ of farms are commodity-based. Individual livestock numbers, traditionally regarded as an indicator of well-being and high financial status, have also become a means of regulating relations with other social institutions, the basis of social mobility of family members (getting education, promotion in career, etc.).

A few responses to the sale of less than half of the production show the level of low-commodity farm (4\%). Families with a small number of livestock, sell it only in case of emergency, so they are insufficiently prosperous. The respondents' opinion, regardless of gender, national identity or territorial possession, does not differ significantly.

About a third of the respondents (32\%) noted that they consume products in the family, sell it only in a small amount. The Kalmyk respondents (35.2\%) who own such a subsidiary farming are twice as much as the Russian respondents who own a low-commodity farming $(18.2 \%)$. The sale of a small amount of farm surplus to a certain extent contributes to solving many financial problems of the family. The goal of running such private subsidiary farming by these families is to ensure survival, primarily the increase in income to the family budget.

More than half of those who participated in the questionnaire survey $(50 \%)$ indicated that the produced products are consumed only in the family. Such kind of response allows us to assert that most of the private subsidiary farming of the population are self-sufficient. To a greater extent, this is typical for the farming of the Russian respondents $(71.4 \%)$ than for the Kalmyk ones $(42.7 \%)$. Thus, for a large part of rural families, the own farmstead is the main, sometimes the only source of income. By means of private subsidiary farming, rural families meet the needs of meat and dairy products, potatoes and vegetables.

The private subsidiary farms of the population are vulnerable because they are not ready to conduct a comprehensive deal-making process concerning purchase prices with "second-hand dealers" by formal and informal entrepreneurs who make purchases directly in the villages. Peasants negotiate with them on unfavorable conditions for themselves. Therefore, retail prices can be multiples of the prices at which "secondhand dealers" purchased products of private subsidiary farming. So, peasants sell mutton in live weight at a rate of 200 rubles per kilogram, and "second-hand dealers" sell it at the market in Elista at 280-300 rubles per kilogram, and if you sell mutton in Moscow, its value reaches 500 rubles a kilo and more. It is obvious that peasants do not receive fair compensation for their hard work.

According to the conclusion of O. P. Fadeeva which we also have taken into account, one of the distinguishing characteristics of the private subsidiary farming system is the motive of economic activity which manifests itself in satisfying the needs of the family (and its community) in products and money, as well as due to other limited financial sources of family budgets [3].

The example with individual farmsteads testifies that they retained their primary function as a source of income or a way to save the current expenses of the rural family, and foremost, they began to function without any contact with the state farm. The owners demonstrate independence, economic initiative and entrepreneurial spirit.

According to the exact definition of O. P. Fadeeva, the structure of family farms has become a kind of buffer for the labour power under the conditions of an excessive labour surpluses and depressed rural labor market or some increase in unemployment (including hidden unemployment). When the structure of large farms began to lose its former positions, viable family farms restrained the process of depopulation of the countryside, initiated by the disintegration of collective farms [3].

The study identified the motivation of rural residents in a projective situation. For this purpose, a closed question was asked: "How would you run your private subsidiary farm if your salary or pension was raised by two to three times?". In our opinion, the income which is about 20-30 thousand rubles, can be considered to be acceptable for the majority of the rural population of the republic. In case the villagers keep their farm for survival, then by means of the increased income they could turn it down.

The survey results show that about $40 \%$ of the respondents, despite the increase in family incomes, will continue to run private subsidiary farm as before. This decision is mostly aimed at by the following respondents: women (45.1\%), the Russians (45.9\%). 
Only few people among the respondents (4\%) who are equally distributed in almost all the analyzed groups (the exception is the Russian respondents - 8.2\%) are ready to take the reverse action - to eliminate the private subsidiary farming.

There are not many people who, with increasing incomes, will reduce their farmstead (5.7\%). Such kind of attitude is equally distributed in almost all the groups under consideration (the exception is the Russian respondents - 3\%). In our opinion, the owners of smallscale farms occasionally sell out farm surplus because people do not have enough wages, they need additional sources of income in solving the current family problems (education of children, medical services, etc.). With a significant increase in wages, such owners are ready to reduce production by moving to a group of selfsufficient farming, or to eliminate a personal farmstead by engaging in other activities.

Half of the respondents (50\%) aim at expanding the private subsidiary farming in the situation under the study. To a greater extent this motivation is characteristic of the male part of the selected groups (56.6\%), the Kalmyk respondents (52.1\%). It is these groups that are traditionally used to cultivating land, raising livestock to support themselves and their families, without the expectation of external factors, help from relatives and other social institutions. It can be supposed that the goal of agricultural activities of half of the rural families is the development of production which indicates the formed market-oriented behavior of the country people.

\section{CONCLUSION}

Thus, with a noticeable increase in "external" income, this part of the sample would not change the intensity of the work on the farm and the respondents are ready to increase it when they have extra money. Such activity in many respects explains the positive trend in the dynamics of agricultural production in the individual sector, observed in the period from the middle of the 2000s.

In terms of the research, the problems that constrained the production in private subsidiary farming were identified as the following ones:

- lack of time to run private subsidiary farming;

- heavy physical activity;

- insufficient support from the state;

- problems with the sales of products;

- inaccessibility or high cost of feed;

- insufficient assistance from agricultural enterprises.

The obtained results of the questionnaire eloquently emphasize that a solid part of the rural residents of the republic of Kalmykia focuses on the maintenance of private subsidiary farming and the production of commodity-based agricultural products.

Thus, the analysis has shown that the development of private subsidiary farming is a "social buffer" because it reduces the severity of social problems, primarily unemployment. Private subsidiary farming creates new jobs, thereby supporting the family budget and providing the consumer market with food products and services. It is necessary to obtain state support for the further development of the private subsidiary farming of the rural population, which should be implemented in the form of concessional loans, support of cooperation and the provision of guaranteed sales channels for products.

The analysis of the materials of the field study made it possible to determine the potential of the rural population, the peculiarities of the modern village of Kalmykia: the ongoing issues associated with labor employment, a fair reward for heavy peasant labor, lower comfort of living compared to the city (lack of water, asphalt roads), insufficient funding of social infrastructure. When asked in terms of the questionnaire "Who can you rely on in solving the current problems?" the vast majority responded that they could rely only on themselves, secondarily - on relatives and friends. No matter how painful it is to realize, others are not yet up to the problems of rural remote areas, they are busy solving other problems.

\section{Acknowledgment}

This article was prepared as part of the research of the Kalmyk scientific centre of the RAS "Development of rural territories of the South of Russia: an integrated analysis of socio-economic processes"

\section{References}

[1] L.Namrueva "The role of private subsidiary farming in the development of the agricultural sector of Kalmykia" [Rol' lichnykh podsobnykh khozyaistv v razvitii agrarnogo sektora Kalmykii (no materialam 20002010-kh gg.)] // Field research, Kalmyk Scientific Center RAS [Polevye issledovaniya KalmNC RAN]. Elista, 2016. pp. 192-204.

[2] T. Nefedova "Three patterns of modern agriculture of Russia: specificity and collaboration" [Tri uklada sovremennogo sel'skogo khozyaistva Rossii: spetsifika i vzaimodeistvie] // Acta Eurasica [Vestnik Evrazii]/ 2002. № 1 (16).

[3] O. Fadeeva "Rural communities and economic structures: from survival to development "[Sel'skie soobshhestva i khozyajstvennye uklady: ot vyzhivaniya $k$ razvitiyu] / edited by Z. I. Kalugina. Novosibirsk: IEIE SB RAS, 2015. 264 p. 